\title{
A LACQUER DUTCH PIPE CASE IN THE TORRALBA COLLECTION
}

This short article examines a rare surviving example of Japanese export lacquer: a Japanese lacquer pipe case. It is particularly interesting, given that only a few such examples in Japanese export lacquer are known worldwide. This particular pipe case was apparently made for export to the Netherlands between approximately 1700 and 1740 .

The case is currently in the Torralba Collection of Oriental Art, in Saragossa, Spain, which belongs to the Fundación Torralba-Fortún. The collection was created by Dr. Federico Torralba (1913- ), Professor of Art History at the University of Saragossa. From an early age, Dr. Federico Torralba was dedicated to collecting artistic objects originating from East Asia, especially from Japan. His entire collection, together with his vast library on the art of East Asia, was donated to the Saragossa Regional Government in 2001, the year when the Foundation bearing his name was founded.

The collection consists of prints, paintings, lacquer, ceramics and ivory objects, as well as other artefacts. Of these Japanese lacquer comprises the principal part of the collection, both in terms of quantity and of quality. More than 200 pieces of Japanese lacquer were collected by Dr. Torralba. The majority are objects made for the Japanese domestic market. They include works dating from the Momoyama period (1573-1603) up to the Early Showa (1926-1945), but the most significant in number are the objects of the Late Edo period (1716-1868). These are pieces that were exported during the Meiji period (1868-1912) and entered European collections during the period of 'Japanism', when Japanese art was very much in fashion, which peaked in the last decades of the $19^{\text {th }}$ century. Unfortunately, some of those collections were sold to dealers. However, Dr. Torralba rescued many pieces from dealers, principally in Paris and Venice, from the 1930s onwards. The Torralba Collection contains several rare examples of Japanese export lacquer. One object in particular is singular in its rarity: and therefore is the subject of this brief text.

This special object is a long wooden case designed for the safekeeping of two Dutch pipes (figs. 1, 2 and 3). The original pipes for which the case was made do not survive. It is covered with Japanese lacquer (urushi). It is $74 \mathrm{~cm}$. (length) by $7 \mathrm{~cm}$. (maximum width) by $8.3 \mathrm{~cm}$. (maximum height). Such pipe cases were executed under specific request, often of a Dutch trader.

The Dutch traders, during the commercial expansion in Asia, commissioned exotic and luxurious cases for their pipes, made in the East, as a demonstration of their supremacy in trade. Elaborate pipe cases were representations of their wealthy lives based on trade and travel, and were a significant status symbol. Similar cases from other Asian localities undoubtedly fulfilled the desires of the rich mercantile class of the Netherlands. An exuberantly carved $18 \mathrm{Am}$ pipe case made of ivory, originating from Sri Lanka dating from the end of the ${ }^{\text {access }}$ 


\section{Figure 1}

Dutch pipe case, Japanese lacquer, 1700 . 1740, I. 74 cm., Fundación Torralba. Fortún, Saragossa, ref. 2002.5.442. Photo: Mugel Gracia: Michun

\section{Figure 2}

Pipe case, Fundación Torralba-Fortún

\section{Figure 3}

Pipe case, Fundación Torralba-Fortún
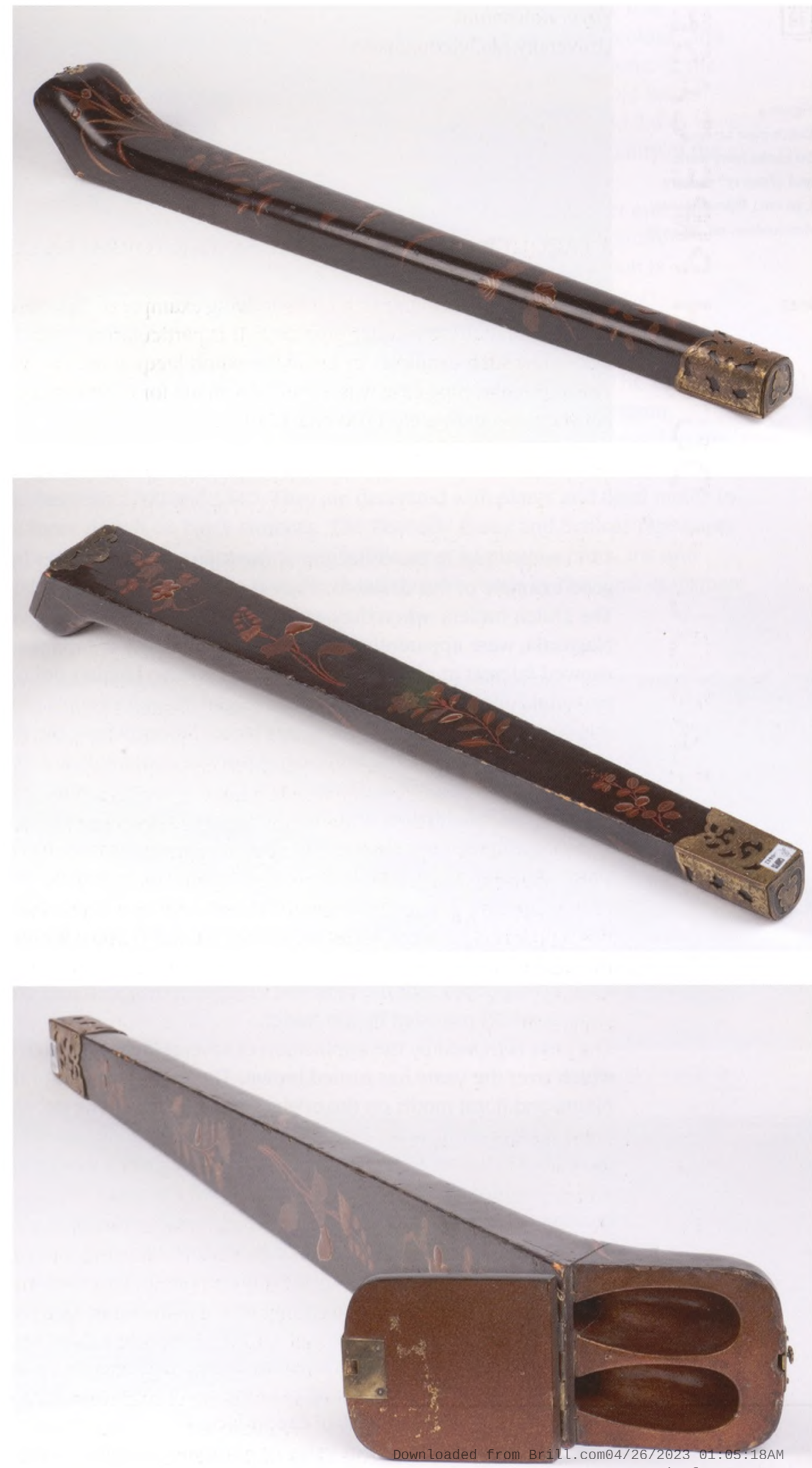


\section{Figure 4}

Dutch pipe case,

Sri Lanka ivory work, end of the $17^{\text {th }}$ century, l. $50 \mathrm{~cm}$., Rijksmuseum, Amsterdam, ref. NG-453

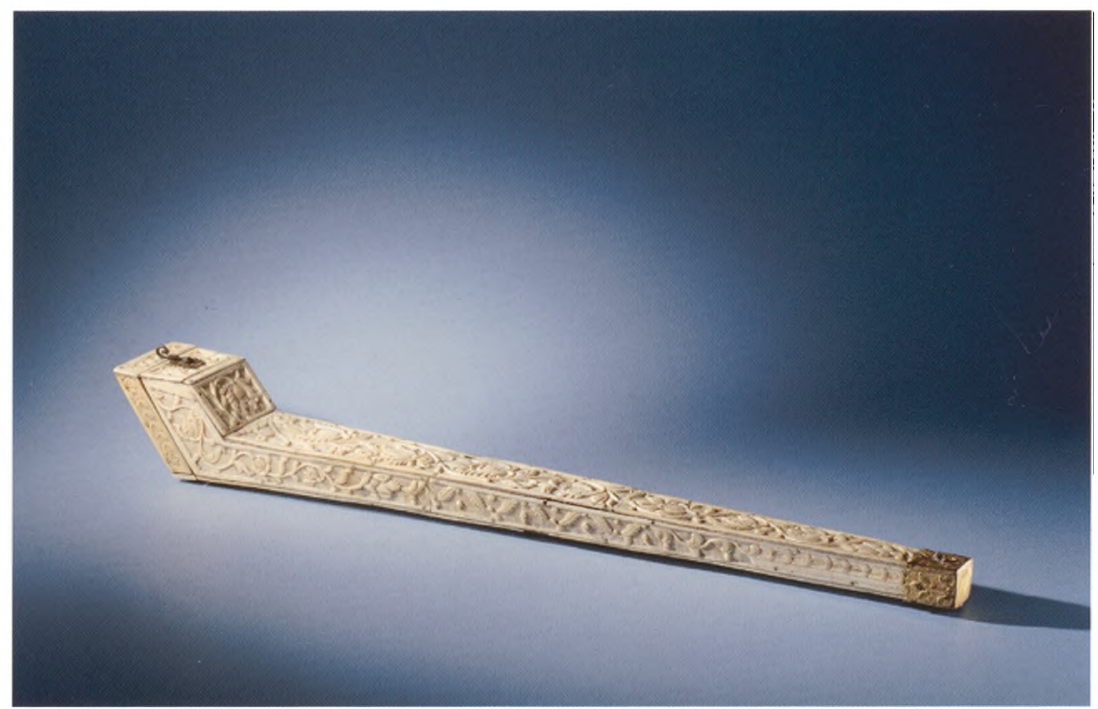

$17^{\text {th }}$ century and in the collection of the Rijksmuseum Amsterdam, is a very good example of this desire for such status symbols (fig. 4). ${ }^{2}$

The Dutch traders, when they arrived at Deshima, the Japanese port in Nagasaki, were apparently fascinated by the beauty of Japanese lacquer, and showed interest in obtaining samples of Japanese lacquer not only for their personal collections but also as commercial items for export to Europe. In this context our pipe case has to be placed. Nevertheless, the fact that so few examples of lacquer Dutch pipe cases survive could indicate that the ordering of such articles might have been just a caprice of those who came to Japan for personal satisfaction, and that they were not common commercial articles. The lacquer pipe case shown here is very long and narrow: rectangular in shape, but with rounded corners. One of the ends is straight and has a metal guard; the other has a curvature rather like a fist or a snake head, and also has a metallic guard. Here the lid is attached: a flat piece that turns on a hinge. The design of this case is not typical of Japanese craftsmen, and it must be supposed that the Japanese craftsmen designed and crafted this case using a model provided by the trader.

The case is treated by the application of several layers of black lacquer, which over the years has turned brown. There are some natural-looking plants and floral motifs on the original black surface. The decoration is of a loose design, far from the tight foliage of Namban style (the Japanese export lacquer of between 1580 and 1630). This loose design was fashionable in the late $17^{\text {th }}$ century and also in the $18^{\text {th }}$ century, the period in which the Dutch dominated the commercial trade between Europe and Japan.

On the front, irises, thistles, vines, chrysanthemums and other plants are found, and on the back, flowering plum trees and other simple plants. These plants on the whole neither represent any specific season (which would have been characteristically Japanese) nor correspond to a traditional Japanese design. They are simply decorative motifs that evoke Japan: suitable for the Dutch demand. The artistic quality of the decoration is only moderate, a common trait in many pieces of export lacquer.

The decoration is carried out using the urushizetechnique. The craftsman 1:05:18 Am applied several pigments, mixed with transparent lacquer, using a via free access 
paintbrush. The colour tone of these decorative motifs is limited; it is principally reddish. The craftsman painted the motifs using one colour, and then added the details of the plants and flowers using a clearer tone. Some leaves and petals are in partial relief. Some maki-e technique (gold flakes sprinkled onto fresh lacquer) can be observed. However, the gold flakes have since lost their intensity of colour, perhaps due to the inferior quality of the original material. The inside of the case is uniformly brown.

The hinge and the metallic guards are made of an alloy of copper and zinc. The hinge and the guard on the straight end are especially beautifully

Figure 5

Dutch pipe case, Japanese lacquer, 1700 1740, I. 76 cm., Rijksmuseum, Amsterdam, ref. AK-NM-6207

\section{Figure 6}

Dutch pipe case, Japanese lacquer, 1700 1740, Peabody Essex Museum, Massachusetts, ref. E85431. Photo: Peabody Essex Museum decorated with motifs of clouds and curving forms. This decoration is perforated, so the lacquer surfaces can be seen through it. This pipe case is an unusual piece that belongs to the pictorial style of Japanese export lacquer, which the VOC (the Dutch East India Company) sent to the Netherlands in the first decades of the $18^{\text {th }}$ century. The Torralba case can be compared with one very similar case in the Rijksmuseum, Amsterdam (Fig. 5), another in the Peabody Essex Museum, Massachusetts (Fig. 6), ${ }^{3}$ and another in the Schlossmuseum, Gotha: ${ }^{4}$ all of which are datable to between 1700 and 1740 . They are decorated with plants and floral motifs in a loose design on black surfaces. The Peabody Essex and Schloss pipe cases are similar in their decorative motifs. The array of plants - plum, iris and peony - is the same. It is possible that they were made by the same craftsman.
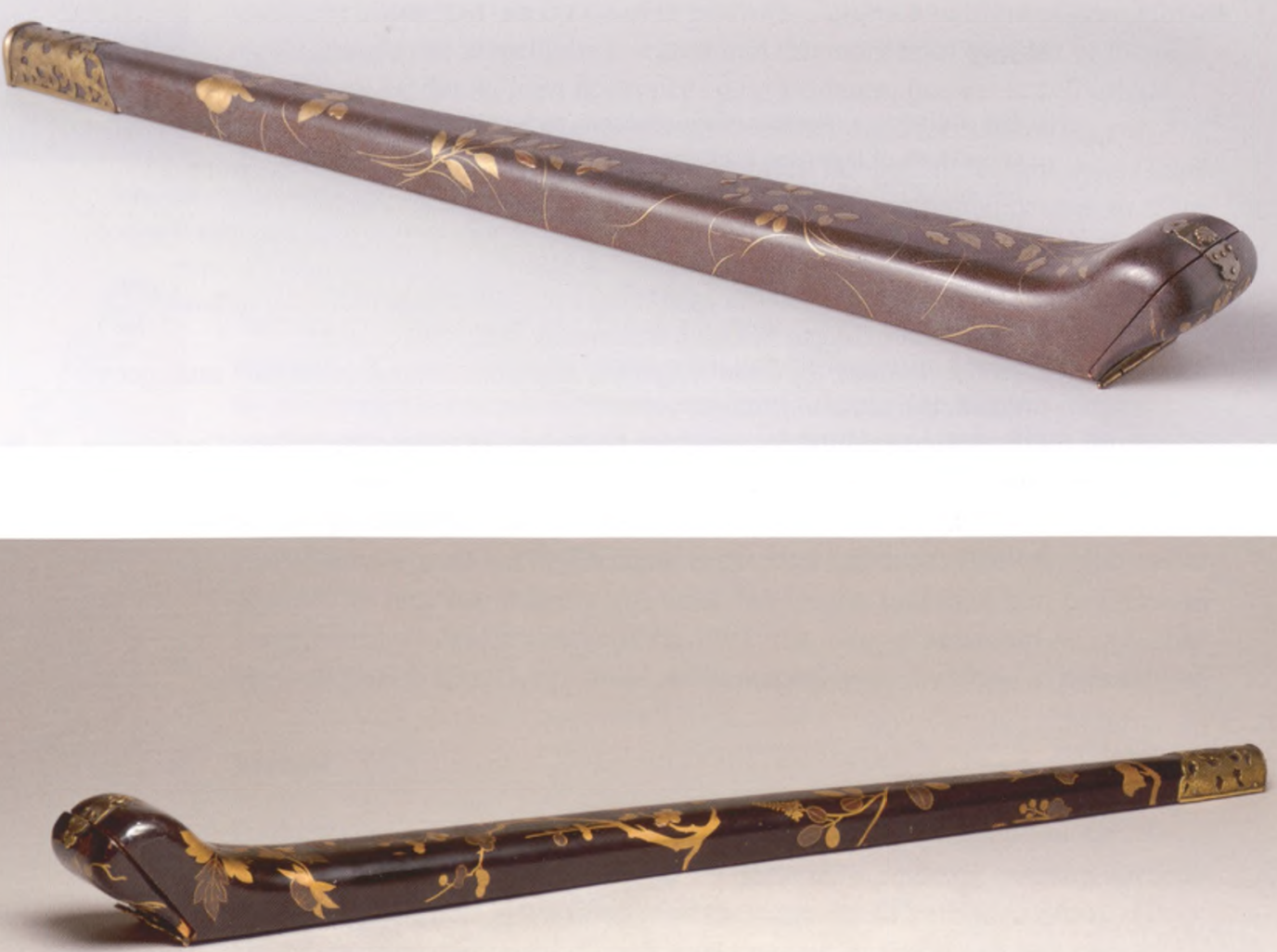
The Rijksmuseum pipe case uses hira maki-e and urushi-e, as does the Torralba, and the Peabody Essex and Schloss pipe cases are also decorated using these techniques. However, the gold and silver hira maki-e technique is used in more areas. The latter two pieces can be considered as more refined and delicate than the Rijksmuseum and Torralba examples.

We cannot, however, ignore another pipe case: that of the Victoria and Albert Museum, London. This model is rather different. The form of the snake-head end is less steep and has a softer curve. On the black surface, there are flower motifs in mother-of-pearl inlay. The mother-of-pearl inlay is frequent in the Namban style (1580-1630) and was still being used during the second third of the $17^{\text {th }}$ century for export lacquer. The metal guard and the hinge are less decorated. However, the most prominent difference is the roughness of lacquer work, which makes it difficult to conclude that it originated in Japan. This pipe case could have been manufactured in South-East Asia as an imitation of Japanese lacquer. In any case, the Victoria and Albert model is presumably older than the others, given its reminiscence of Namban style. The study of Impey and Jörg reveals the presence of another case through historical documentation. ${ }^{5}$ It is a lacquer pipe case that Augustus the Strong of Saxony (1670-1733) possessed; it was bequeathed to him by Daniel Friedrich Raschke, his agent in the Netherlands in 1708 and 1709. The Torralba pipe case, for lack of historical information, can be dated in accordance with the other abovementioned examples to between 1700 and 1740. It entered the Torralba Collection from the French art market during the 1980 s through Portuondo, a dealer in Bilbao (Spain), but, alas, further information regarding its provenance has yet to be found.

\section{Notes}

1. The author is a member of the research project 'Cataloguing and study of the collections of Japanese traditional and contemporary art in Spain': HAM200805784/ARTE. My grateful thanks to Christiaan Jörg (Leiden University), Menno Fitski and Jan van Campen (Rijksmuseum Amsterdam), Gerald Marsella (Peabody Essex Museum), Julia Hutt (Victoria \& Albert Museum) and John Doherty.

2. Met Andere Ogen; 400 jaar afbeeldingen van Europeanen door verre volkeren (exhibition catalogue Museum Nusantara), Delft, 1986, cat. 25.

3. Worlds Revealed; the dawn of Japanese American exchange (exhibition catalogue Edo-Tokyo Museum), Tokyo, 1999.

4. H. Bräutigam, Schätze japanischer Lackkunst auf Schloss Friedenstein, Catalogue of the collection of the Schlossmuseum, Gotha, 1998, p. 98, cat. 166; O. Impey and C. Jörg, Japanese Export Lacquer (1580-1850), Amsterdam, 2005, p. 312.

5. Impey and Jörg, Op.cit. (noot 4), pp. 309-312. 